\title{
A CASE OF ARTHROGRYPOSIS MULTIPLEX CONGENITA ASSOCIATED WITH MATERNAL SEPTATE UTERUS
}

\author{
Hae Kyung Kim, MD', Hoon Kyu Oh, MD², Seong Yeon Hong, MD \\ Departments of ${ }^{1}$ Obstetrics and Gynecology, ${ }^{2}$ Pathology, Catholic University of Daegu School of Medicine, Daegu, Korea
}

Arthrogryposis multiplex congenita (AMC) is a congenital disorder showing multiple joint contractures. Although there are characteristic features in morphology, it is difficult to diagnose prenatally by ultrasonography. The causes of AMC include abnormalities of central nervous system, myopathies, connective tissue disorders, and intrauterine environmental factors such as oligohydramnios or uterine anomalies. We describe a case of prenatally diagnosed and postnatally evaluated AMC associated with maternal septate uterus.

Keywords: Arthrogryposis multiplex congenita; Septate uterus; Prenatal diagnosis

선천성 다발성 관절굽음증(arthrogryposis multiplex congenital)은 하 나의 질환이라기보다는 다발성 관절의 구축을 보이는 증상 복합체라고 할 수 있다. 발생빈도는 출생아 10,000명당 1-3명 정도로 알려져 있으 며[1], 임신초기의 태아 운동장애로 인해 초래되는 관절의 이차적인 구 축을 공통적인 특징으로 한다. 원인은 매우 다양해서 300 가지 이상의 질환과 관계되어 있는 것으로 보고된다.

저자들은 임신 21주에 산전 초음파검사를 통해 중격자궁과 연관된 선천성 다발성 관절굽음증을 진단하였고 사산아에 대한 자기공명영상 검사, 부검, 근육생검, 전자현미경검사 및 유전학적 검사 등을 통해 원 인에 대한 규명을 시행하였던 1예를 경험하였기에 보고하는 바이다.

\section{증 례}

환 자: 김 0 0, 24세

주 소: 임신 5 주 4 일, 개인 산부인과에서 우측 자궁각임신이 의심되어 전원되었다.

산과력: 0-0-0-0

과거력: 임신 중 약물이나 방사선에 노출된 경력은 없었고 산모와 배 우자 모두 신경학적 질환, 근육병증, 결합조직 질환 및 기타 유전학적 질환은 없었다.

가족력: 산모 및 배우자의 가계에 유전 질환이나 선천성 기형의 가족 력은 없었다.

초음파 소견: 본원에서 시행한 초음파검사에서 우측 자궁각 근처에서 임신낭이 관찰되었으나 자궁내막과 연결되어 있었고 임신낭 주위의 자 궁근층이 충분한 두께를 가지고 있어 자궁각임신은 배제되었다. 임신
초기 초음파에서 쌍각자궁(bicornuate uterus)으로 의심되었고 12주까 지는 우측 자궁강내에 임신낭과 태아가 존재하였다. 16주에 시행한 초 음파에서 자궁저부는 궁상(arcuate uterus)으로 보였으며 자궁저부에서 자궁체부 하방까지 두꺼운 자궁중격이 관찰되었다. 태아 머리 및 상체 는 자궁중격 우측에, 하체는 중격 좌측에 위치하였고 사지의 구축은 관 찰되지 않았으나 중격 및 좁은 자궁강으로 인해 움직임은 제한되어 보 였다(Fig. 1). 임신 21주에 시행한 검사에서 태아 예상체중은 $296 \mathrm{~g}$ 으 로 주수에 비해 작았으며 양측 상하지의 모든 관절에서 구축이 관찰되 었다. 어깨관절의 내전(adduction), 팔굽관절과 손목관절의 굴곡변형 (flexion deformity), 엉덩이관절의 내전 및 무릎관절의 굴곡변형 소견을 보였으며 겹친 손가락(overlapping fingers)과 곤봉발(club feet)의 모양 을 보였다. 하지에서 좀 더 심한 구축을 보였으며 시간을 경과하여 관 찰하여도 사지의 움직임은 거의 보이지 않았으며(Fig. 2), 다른 태아기

Received: 2012.6.5. Revised: 2012.7.17. Accepted: 2012.7.26. Corresponding author: Seong Yeon Hong, MD

Department of Obstetrics and Gynecology, Daegu Catholic University Medical Center, 33 Duryugongwon-ro 17-gil, Nam-gu, Daegu 705-718, Korea Tel: +82-53-650-4078 Fax: +82-53-650-4078

E-mail: magu815@cu.ac.kr

This is an Open Access article distributed under the terms of the Creative Commons Attribution Non-Commercial License (http://creativecommons.org/licenses/ by-nc/3.0/) which permits unrestricted non-commercial use, distribution, and reproduction in any medium, provided the original work is properly cited.

Copyright $\odot$ 2012. Korean Society of Obstetrics and Gynecology 


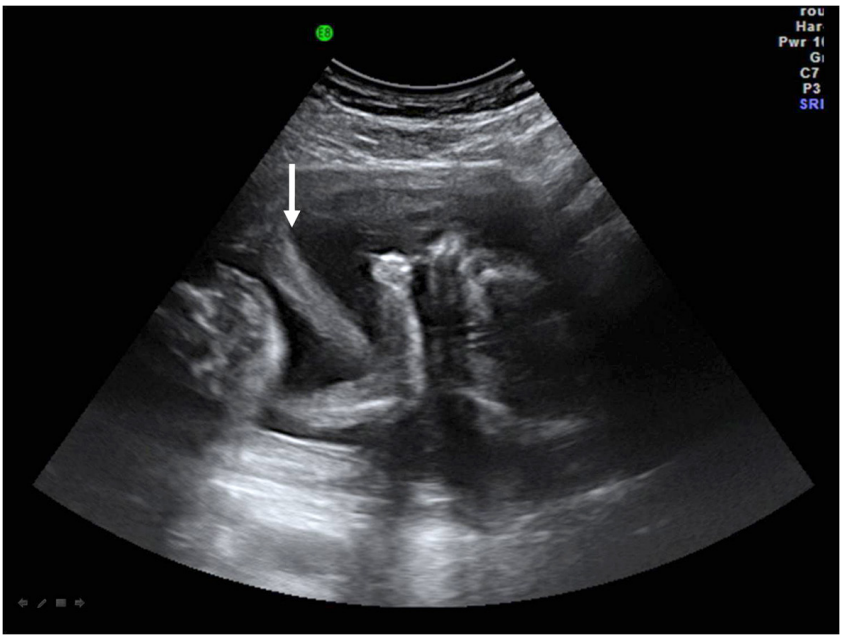

Fig. 1. Coronal scan of gravid uterus shows that a thick septum is extended to lower uterine cavity. The head and upper portion of the fetus is located in the right uterine cavity and lower portion in the left cavity (arrow, septum).

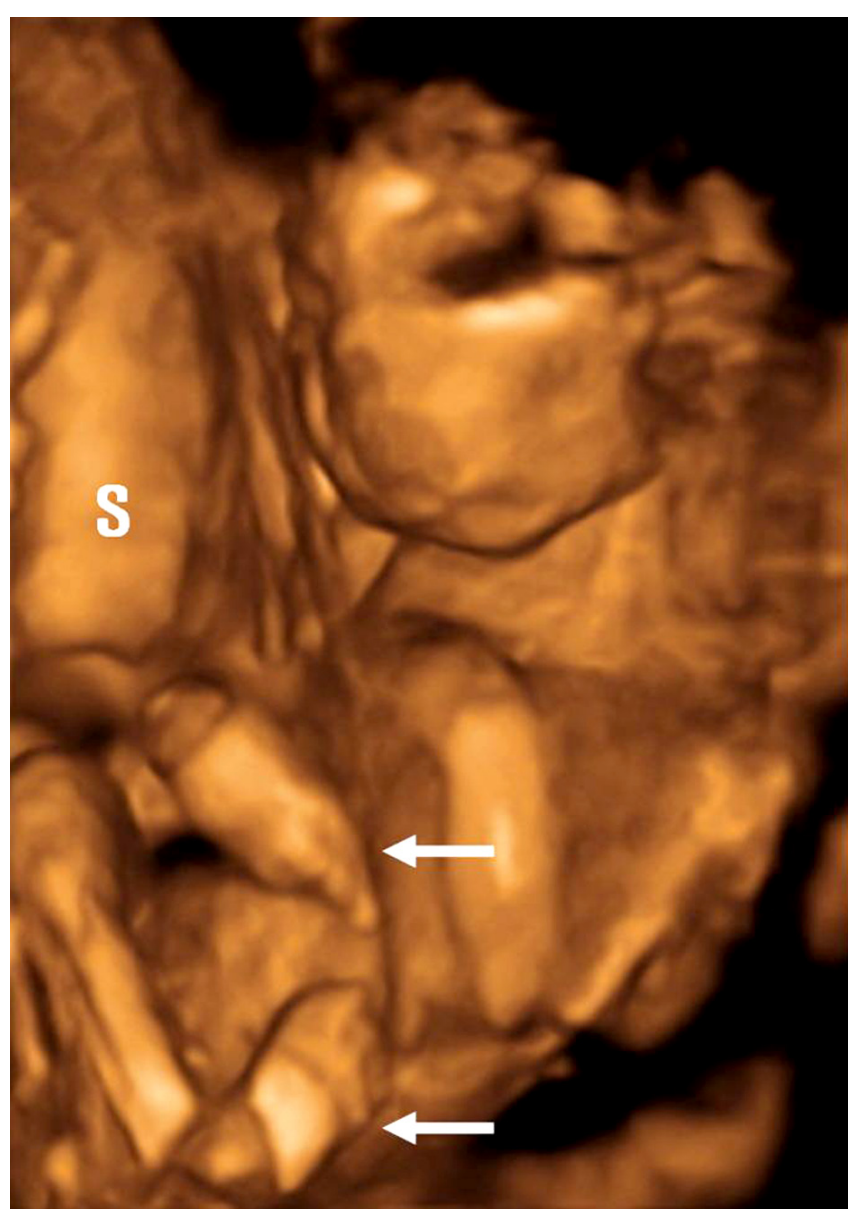

Fig. 2. 3-D scan image of multiple joint contractures ( $S$, setum; arrow, wrist deformity and club foot).
형은 관찰되지 않았다. 저자들은 이와 같은 소견을 통해 선천성 다발성 관절굽음증으로 진단하였다. 질환의 예후에 대해 충분히 상의한 결과 산모와 배우자가 강력히 원해 동의하에 임신을 종결하였다.

산전 유전학적 검사 소견: 양수천자를 통한 핵형분석에서 정상핵형 을 보였고 근긴장성 이영양증(myotonic dystrophy)의 확인을 위한 dystrophia myotonica protein kinase 유전자검사에서 이상은 없었다.

사산아 소견: 육안적 관찰에서는 산전 초음파 소견과 같이 다발성 관 절구축을 보였다(Fig. 3). 사산아에 대한 자기공명영상검사에서 중추신 경계와 척추의 변형이나 구조적인 이상은 찾아볼 수 없었다. 보다 정확 한 원인을 알아보기 위해 산모 및 보호자의 동의하에 부검을 시행하였 고 내부 장기에서는 특이 소견을 보이지 않았으며 사산아의 대뇌, 소 뇌, 척수 및 근육생검을 시행하였다. 중추신경계에 대한 조직검사에서 는 특이한 병리 소견을 보이지 않았고, 근육생검에서는 근육세포의 위 축과 근육세포 사이의 섬유화 및 광범위한 지방침착을 보여 선천성 다 발성 관절굽음증에 부합하는 소견을 나타내었으나 특이한 근육병증의 소견은 없었다. 전자현미경검사에서도 근육세포와 미토콘드리아의 이 상 소견은 없었다(Fig. 4).

\section{고 찰}

선천성 다발성 관절굽음증은 1841 년에 Otto에 의해 처음으로 기술 되었으며 1923년 Stern이 arthrogryposis multiple congenita이라는 용 어를 처음 사용하였다[2]. 국내에서는 1961년 Chung과 Park [3]에 의 해 처음으로 보고되었다. 빈도는 출생아 10,000명당 1-3명에서 발생 하며, 성별은 인종에 따라 약간씩 차이가 있지만 거의 유사하다[4].

이 질환은 임신초기의 태아 운동장애로 인해 초래되는 관절의 이차 적인 구축을 공통적인 특징으로 한다. Lin 등[5]은 동물 실험을 통해 임 신 10-12주에 태아운동을 제한시키면 관절의 구축이 유발될 수 있다 고 하였다. 원인은 매우 다양한데, 크게 중추신경계, 척수 및 말초신경 계를 침범하는 신경계의 이상, 근무력증, 근이영양증, 미토톤드리아 이 상 등의 근육병증, 기타 관절의 이상을 가져오는 결합조직질환, 그리고 양수과소증이나 자궁기형 등으로 인해 자궁내 태아 운동제한을 가져오 는 경우로 나눌 수 있다[6].

중추신경계 이상에는 신경세포 이주장애(neuronal migration disorder), 소뇌 형성부전, 통압뇌증(holoprosencephaly), 추체의 퇴화 (pyramidal tract degeneration) 등이 있으며[7], 척수 이상에는 전각 세포(anterior horn cells) 소실이 가장 흔한 원인으로 알려져 있다. 근 육 질환으로 선천성 근무력증(congenital myasthenia), 선천성 근긴장 성 이영양증(congenital myotonic dystrophy), 근육병증(myopathy), 자 궁내의 근육염(Intrauterine myositis), 미토콘드리아 이상(mitochondrial disorder) 등이 있으며[8], 결합조직 질환으로는 다발성 군날개증후군 (multiple pterygium syndrome), 골유합, 관절 발달의 장애, 유기영양 왜 소 발육증(metatropic dwarfism), 변형 이형증(diastrophic dysplasia) 등 이 있다[6]. 자궁 또는 모체 요인으로 공간의 제한을 초래하는 양수과 


\section{KOREAN JOURNAL OF OBSTETRICS \& GYNECOLOGY}

Hae Kyung Kim, et al. Arthrogryposis multiplex congenita
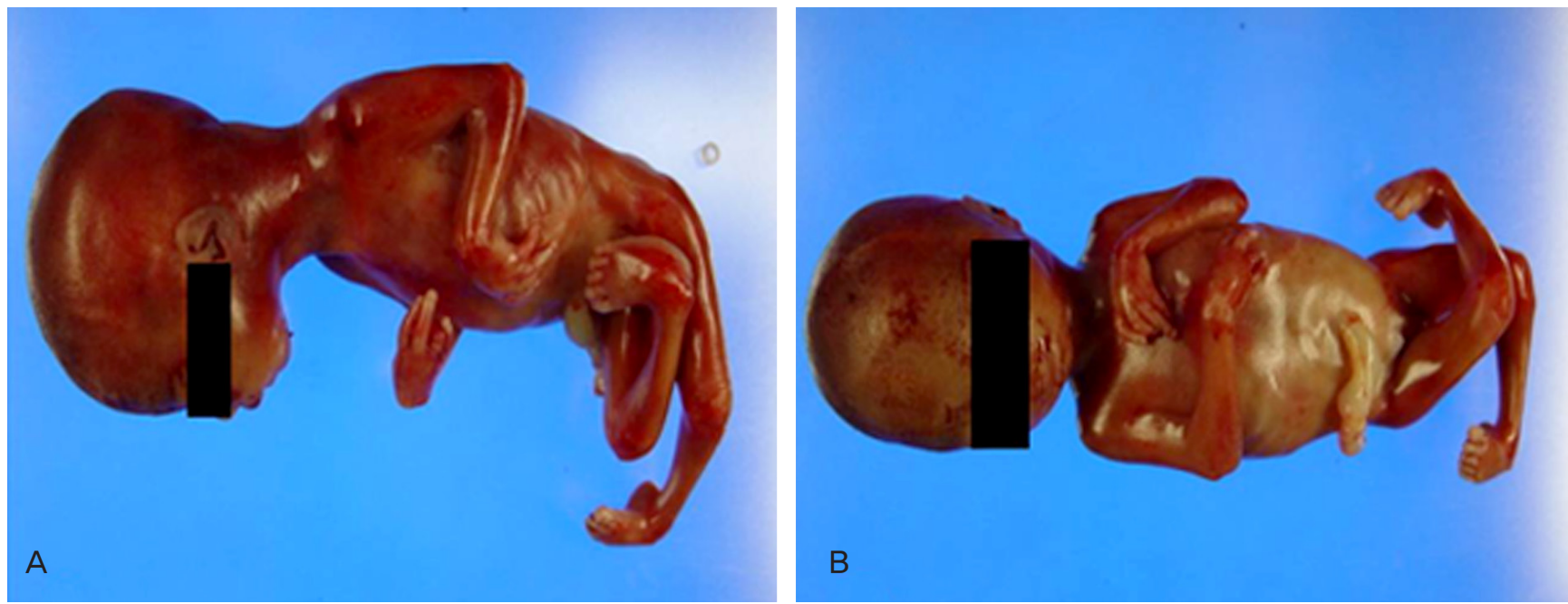

Fig. 3. Gross appearances of the fetus with multiple joint contractures corresponding arhtrogryposis multiplex congenita.
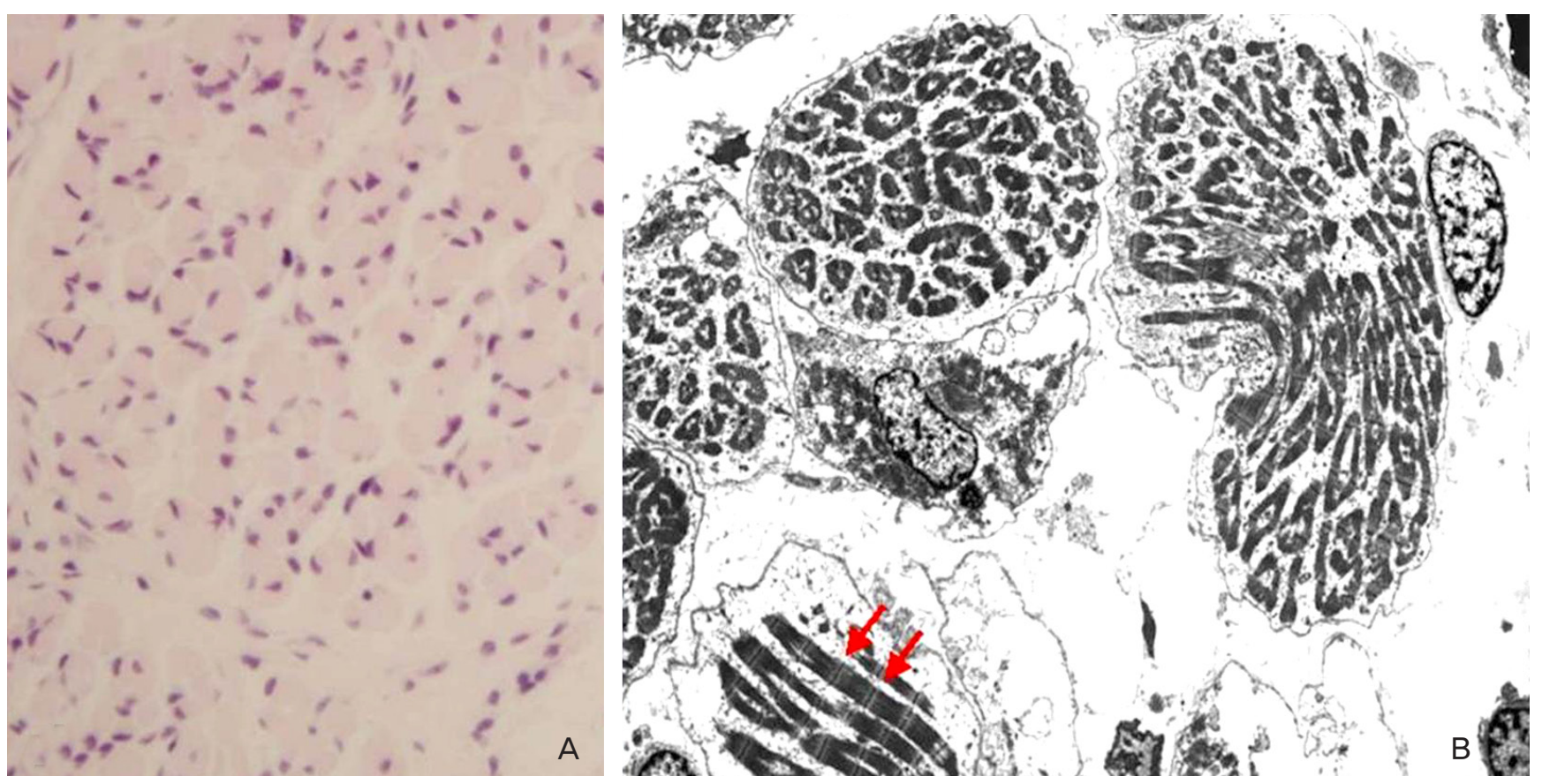

Fig. 4. (A) High power microscopic findings of calf muscle shows mild size variation of skeletal muscle fiber and interstitial edema (H\&E, $\times 400)$. (B) Electron microscope shows well preserved myofbrils and sarcomeres (arrow). There is no abnormal mitochondria nor cytoplasmic inclusion $(\times 1,500)$.

소증, 자궁기형, 평활근종을 포함한 자궁내 종양, 다태임신 등이 있으며 [8], 태반 혈류 부족(placental insufficiency), 분만 전 출혈로 태아의 혈 액공급이 감소될 경우 태아의 신경세포, 근육 및 빼에 초기 손상이 생 겨 관절구축이 초래될 수 있다. 당뇨, 근무력증, 다발성 경화증, 바이러 스 등의 감염, 고열과 같은 모체 질환 및 큐라레(curare), 알코올, 페니 토인 등의 약물복용, 약물남용, 임신 중 외상(trauma) 또한 원인이 될 수 있다[6]. 상염색체 우성유전(autosomal dominant), 상염색체 열성유 전(autosomal recessive), 성염색체 열성유전(X-linked recessive) 등의
유전학적 원인도 약 $30 \%$ 에서 관련이 있는 것으로 보고된다[9].

관절 구축은 다양하게 나타날 수 있지만 대부분 대칭적으로 양측 상 하지가 동시에 이환된다. 매우 심한 경우에는 턱관절이나 척추까지 이 환되기도 한다. 합병증으로는 척추측만증, 폐형성부전, 호흡부전, 발육 지연, 안면 및 턱관절 이상, 복벽 탈장 등이 있으며, 일반적으로 지능이 나 언어 능력은 정상적이다.

관절의 구축은 임신 16-18주 이전에는 저명하지 않아서 임신 제1삼 분기에 진단되는 경우는 거의 없으며 대부분 임신 제2분기나 임신 제3 
분기에 진단된다. 하지만 최근에는 초음파 기기가 발전하고 초음파 표 지자가 도입되어 조기 진단에 도움을 주기도 한다. 염색체 이상이나 다 른 동반 기형이 동반되는 경우에는 조기진단이 가능하다. 임신 제1삼 분기에 태아 목덜미투명대 두께의 증가가 관절 구축을 보이기 전에 나 타날 수 있으며[5], 목덜미 활액낭종(cystic hygroma)은 치사성 군날개 증후군과 관련이 있다.

철저한 원인 규명은 산모와 배우자에게 예후와 재발 여부에 대한 설 명을 위해 중요하다. 원인 규명을 위해서는 신경전달검사, 근전도검사, 관절과 중추신경의 컴퓨터단층촬영이나 자기공명영상, 근육생검, 부검, 산모의 과거력을 포함한 세밀한 문진, 염색체검사, 유전학적 검사 등이 시행되어야 한다[8,10-12].

저자들은 본 증례에서 중격자궁이 선천성 다발성 관절굽음증의 원인 으로 추정되었지만 다음 임신에서 재발에 대한 정확한 예측 및 상담을 위해 철저하고 심도 깊은 원인 규명을 시행하였다. 이를 위해 부모의 현병력, 과거력과 가족력에 대한 세밀한 문진 및 신경과적 검사, 태아 의 염색체검사, 부모의 근긴장성 이영양증에 대한 유전학적 검사, 사산 아에 대한 자기공명영상검사, 부검, 대뇌, 소뇌, 척수 및 다양한 부위의 근육생검 및 전자현미경검사를 시행하여 최종적으로 중격자궁으로 인 한 임신초기의 태아 운동제한을 원인으로 추정하였다. 이와 같은 소견 을 바탕으로 자궁경하 자궁중격절제술을 시행하였고 본 증례의 산모는 다음 임신에서 건강한 아이를 분만하였다.

\section{References}

1. Hall JG. Genetic aspects of arthrogryposis. Clin Orthop Relat Res 1985;(194):44-53.

2. Fassier A, Wicart P, Dubousset J, Seringe R. Arthrogryposis multiplex congenita. Long-term follow-up from birth until skeletal maturity. J Child Orthop 2009;3:383-90.

3. Chung IH, Park BM. A case of Arthrogryposis multiplex congenita. J Korean Med Assoc 1961;4:62-4.

4. Mennen U, van Heest A, Ezaki MB, Tonkin M, Gericke G. Arthrogryposis multiplex congenita. J Hand Surg $\mathrm{Br}$ 2005;30:468-74.

5. Lin IW, Chueh HY, Chang SD, Cheng PJ. The application of three-dimensional ultrasonography in the prenatal diagnosis of arthrogryposis. Taiwan J Obstet Gynecol 2008;47:75-8.

6. Hall JG. Arthrogryposis multiplex congenita: etiology, genetics, classification, diagnostic approach, and general aspects. J Pediatr Orthop B 1997;6:159-66.

7. Vuopala K, Leisti J, Herva R. Lethal arthrogryposis in Finland-a clinico-pathological study of 83 cases during thirteen years. Neuropediatrics 1994;25:308-15.

8. Gordon N. Arthrogryposis multiplex congenita. Brain Dev 1998:20:507-11.

9. Zori RT, Gardner JL, Zhang J, Mullan MJ, Shah R, Osborn AR, et al. Newly described form of $X$-linked arthrogryposis maps to the long arm of the human X chromosome. Am J Med Genet 1998:78:450-4.

10. Bamshad M, Van Heest AE, Pleasure D. Arthrogryposis: a review and update. J Bone Joint Surg Am 2009;91 Suppl 4:40-6.

11. Hardwick JC, Irvine GA. Obstetric care in arthrogryposis multiplex congenita. BJOG 2002;109:1303-4.

12. Kang PB, Lidov HG, David WS, Torres A, Anthony DC, Jones $H R$, et al. Diagnostic value of electromyography and muscle biopsy in arthrogryposis multiplex congenita. Ann Neurol 2003;54:790-5.

\section{산모의 중격자궁과 연관된 선천성 다발성 관절굽음증 1 예}

대구가톨릭대학교 의과대학 '산부인과학교실, ${ }^{2}$ 병리학교실

김혜경, 오훈규 ${ }^{2}$, 홍성연

선천성 다발성 관절굽음증은 다발성 관절의 구축을 보이는 선천적 이상이다. 특징적인 형태학적 이상을 보이나 산전에 초음파로 진단하 는 것은 어렵다. 선천성 다발성 관절굽음증의 원인은 크게 중추신경계의 이상, 근육병증, 결합조직 질환, 그리고 양수과소증이나 자궁기형 등의 자궁내 환경적인 요인으로 나눌 수 있다. 저자들은 중격자궁을 가진 산모에서 산전초음파로 산전에 선천성 다발성 관절굽음증을 진 단하고 원인 규명을 시행한 1 예를 경험하였기에 간단한 문헌고찰과 함께 보고하는 바이다.

중심단어: 선천성 다발성 관절굽음증, 중격자궁, 산전진단 